\title{
A model for hydraulic conductivity of compacted bentonite - inclusion of microstructure effects under confined wetting
}

\author{
TIAN CHEN*, MAJID SEDIGHI†, ANDREY JIVKOV*, SURESH SEETHARAM† and HAILONG WANG§
}

\begin{abstract}
Contribution by Hailong Wang
A model for hydraulic conductivity of compacted bentonite by taking microstructure effects into account was proposed by Chen et al. (2021). The discusser would like to discuss with the authors the terminology related to bentonite and the application of their model. The authors may have misunderstood or misused the terms 'clay', 'clay mineral', 'bentonite', 'smectite' and 'montmorillonite' in the section entitled 'Evolution of microstructure of compacted smectite during wetting', which may make it difficult for readers to follow the content.
\end{abstract}

(a) Montmorillonite, referring to Moore \& Reynolds (1997: p. 155), is a clay mineral in the dioctahedral smectite group.

(b) Smectite, also referring to Moore \& Reynolds (1997: p. 155), is the name for a group of minerals, both dioctahedral and trioctahedral, all of which display the startling property of being able to expand and contract their structures while maintaining two-dimensional crystallographic integrity. It includes clay minerals such as montmorillonite, bidellite, nontronite and so on (Moore \& Reynolds, 1997: p. 155; Poppe et al., 2001).

(c) Clay may be defined very differently depending on disciplines (Rautureau et al., 2007: p. 7). On the one hand, in geotechnical engineering, clay is defined as a material with a size of less than several $\mu \mathrm{m}$ (usually $2 \mu \mathrm{m}$ or $5 \mu \mathrm{m}$ ). On the other hand, to geologists or mineralogists, clay may be a term for a rock made of at least $50 \%$ materials of less than $2 \mu \mathrm{m}$ or a term for an aggregate or mixture of minerals of fine granularity (Moore \& Reynolds, 1997: p. 3; Mitchell \& Soga, 2005: p. 35; Rautureau et al., 2007: p. 7).

(d) Clay minerals, referring to Rautureau et al. (2007: p. 8), are fine-grained hydrous phyllosilicates, minerals of planar or non-planar structures that could impart plasticity (if the right amount of water is added) and hardening (if dried or fired) to the clay in which they occur. Clay minerals are not defined a priori as fine-grained minerals because clays are fine-grained, but rather they may be of any crystallite size so that the term 'clay mineral' is consistent with the definition of mineral, which is unrelated to crystallite size (Rautureau et al., 2007: p. 8).

\footnotetext{
* Department of Mechanical, Aerospace and Civil Engineering, School of Engineering, The University of Manchester, Manchester, UK.

$\dagger$ Department of Mechanical, Aerospace and Civil Engineering, School of Engineering, The University of Manchester, Manchester, UK (Orcid:0000-0002-5104-5781).

* Engineered and Geosystems Analysis Unit, Belgian Nuclear Research Centre, SCK-CEN, Mol, Belgium.

$\S$ Global Center for Science and Engineering, Waseda University, Tokyo, Japan (Orcid:0000-0001-8814-6351).
}

(e) Bentonite is an absorbent swelling material consisting mostly of clay minerals in the smectite group, particularly montmorillonite (Moore \& Reynolds, 1997: p. 16; IMA-NA, 2021; Wikipedia, 2021).

With the above-mentioned definitions, the relationship between some materials may be illustrated by Fig. 12 . Bentonite may be a clay or have a major component of clay-sized particles, but it may also be of stone size (e.g. bentonite ore). It is definitely not, however, a clay mineral or equal to montmorillonite or semetite. Clay minerals may be clay-sized, while they may also be of colloidal size (e.g. $<1 \mu \mathrm{m}$ ). With reference to the content of the paper under discussion, there are many instances that are not expressed properly. Here, the discusser selects just one as an example: in the first paragraph of the section entitled 'Pore classification and structure of compacted bentonite', there is the description 'The microstructure of compacted bentonite consists of an assemblage of basic unit layers (i.e. tetrahedral-octahedral-tetrahedral (TOT)) that form clay particles, aggregates and clusters' (Tournassat et al., 2011; Jacinto et al., 2012; Chen et al., 2019). Clearly, it would be more proper to replace the term 'bentonite', which also includes materials other than clay minerals in the smectite group, with 'montmorillonite' or 'TOT type clays'.

Misuse/misunderstanding of some terms would also affect the application of their model. The pore system for compacted bentonite that they proposed (Fig. 1) and equations (3)-(10) would be appropriate only if the soil element they modelled consists of minerals belonging just to the smectite group. In the cases of the bentonites they evaluated, GMZ, Kunigel-V1, MX-80 and Febex, the montmorillonite contents are in the range of $48-92 \%$. The existence of other components, as shown in Fig. 13, means that their equations (3)-(10) could not be simply applied to make the prediction.

\section{Authors' reply}

Chen et al. (2021) propose a model for hydraulic conductivity of compacted bentonite under constrained swelling. The context is the potential use of bentonite as an engineered barrier in underground repositories for high-level radioactive waste. Specifically, compacted bentonite is considered as a buffer in designs where repositories are hosted in crystalline rocks. The discusser presents two areas where further clarifications would assist better understanding the model: $(a)$ the terminology used to describe the material and $(b)$ the model application to bentonite containing non-smectite minerals (i.e. the effects of impurity). The authors understand that there is hardly a uniform nomenclature across all disciplines for terms such as clay and clay minerals (Bergaya \& Lagaly, 2006), and do not seek a consensus about the meaning of such terms and those outlined and defined by the discusser. Rather the authors 


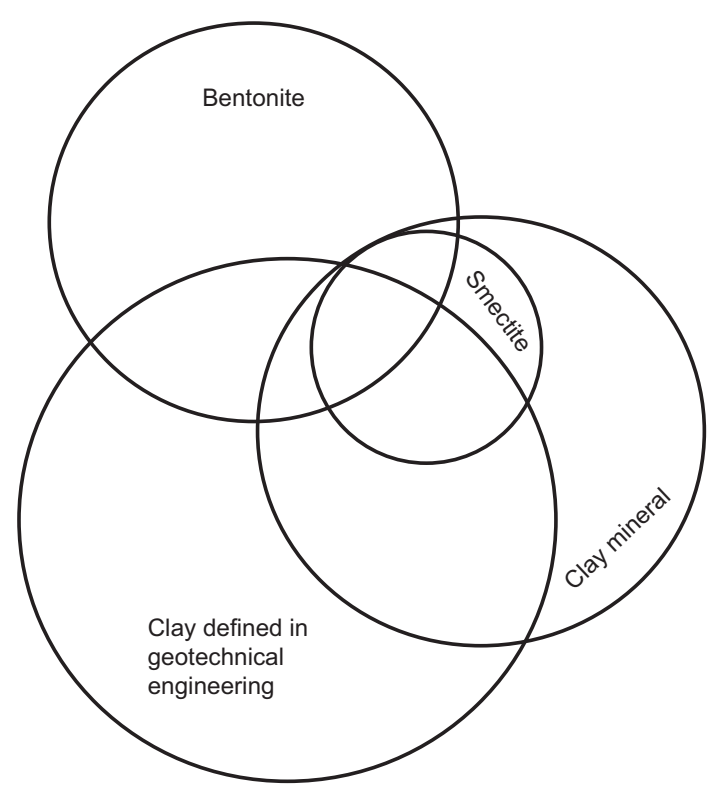

Fig. 12. Relationship between some materials

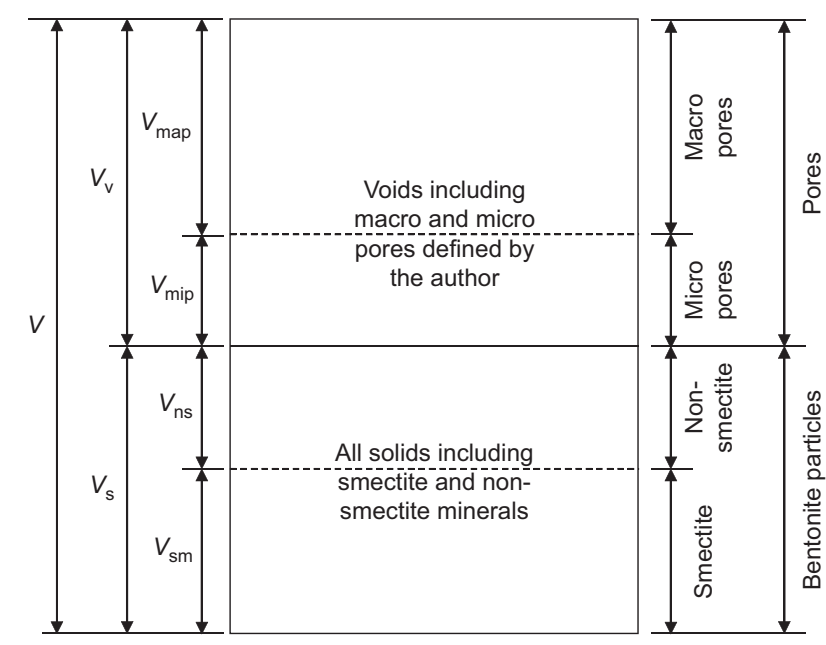

Fig. 13. Components of a bentonite element

focus on providing further clarifications about the terminology used in the paper and the way the model is applied to bentonite.

They refer to bentonite as a natural clay, composed primarily of smectite minerals (Pusch, 2015). Montmorillonite is one of the minerals in the smectite group (Pusch \& Yong, 2006). Commercially available bentonites, such as MX-80, Febex, Kunigel and GMZ, do contain a range of non-smectite minerals - for example, quartz, feldspar, calcite and other accessory minerals - but the most common smectite mineral is montmorillonite. Therefore, the authors use the terms smectite and montmorillonite interchangeably.

A key component of the model by Chen et al. (2021) is the evaluation of the amount of water within the layers of smectite present in bentonite. This water is contained in the interlayer porosity, referred to as the microporosity. Fig. 1 in the paper by Chen et al. (2021) and the discussion in that section refer to the microstructure of smectite, not the bentonite as a whole, and specifically provide a schematic representation of unit layers and aggregates of smectite layers in the compacted bentonite system. A solid-solution model for hydration and dehydration of smectite had been used previously by Chen et al. (2021) to calculate the microporosity. The solid-solution model was based on the original work by Ransom \& Helgeson (1994). This is a generic model applicable to the smectite family but widely applied in the literature to montmorillonite-rich clays (e.g. Vieillard et al., 2011; Jové-Colón et al., 2013; Sedighi \& Thomas, 2014). Sedighi \& Thomas (2014) adopted and upscaled the solid-solution model by Ransom \& Helgeson (1994) to calculate the microporosity (interlayer porosity) of compacted bentonite. This model has been used by Chen et al. (2021) in equation (4), which relates the volume of the interlayer porosity and the dry density of smectite; $\rho_{\mathrm{d}}^{\mathrm{sm}}$. For bentonite containing a range of non-smectite minerals, the term $\rho_{\mathrm{d}}^{\mathrm{sm}}$ refers to the partial dry density of smectite, calculated by Idemitsu et al. (1995), Liu et al. (2003) and Sedighi \& Thomas (2014)

$$
\rho_{\mathrm{d}}^{\mathrm{sm}}=\left[1-\left(1-X_{\mathrm{sm}}\right)\left(\frac{\rho_{\mathrm{d}}}{\rho_{\mathrm{im}}}\right)\right]^{-1} X_{\mathrm{sm}} \rho_{\mathrm{d}}
$$

where $X_{\mathrm{sm}}$ is the mass fraction of smectite in the bentonite composition; $\rho_{\mathrm{d}}$ is the dry density of compacted bentonite (bulk and measurable); and $\rho_{\text {im }}$ denotes the density of the non-smectite minerals or impurities.

By using equation (23), the effects of impurities present in commercially available bentonite are reflected in the dry density used in the calculation of microporosity - that is, $\rho_{\mathrm{d}}^{\mathrm{sm}}$ is lower than $\rho_{\mathrm{d}}$, depending on the mass fraction of smectite in bentonite. Therefore, the presence of non-smectite minerals has been considered in the applications and validations of the model for different bentonite clays presented by Chen et al. (2021). The authors conclude that the model is applicable to bentonite clays containing primarily smectite (commonly montmorillonite) and non-smectite constituents (regarded as impurities).

\section{REFERENCES}

Bergaya, F. \& Lagaly, G. (2006). General introduction: clays, clay minerals, and clay science. In Handbook of clay science (eds F. Bergaya, B. K. G. Theng and G. Lagaly). Developments in clay science vol. 1, pp. 1-18. Amsterdam, the Netherlands: Elsevier.

Chen, T., Sedighi, M., Jivkov, A. \& Seetharam, S. C. (2019). Unsaturated hydraulic conductivity of compacted bentonite: revisit of microstructure effects. In Proceedings of the 8th international congress on environmental geotechnics volume 2. ICEG 2018 (eds L. Zhan, Y. Chen and A. Bouazza), pp. 544-550. Singapore: Springer.

Chen, T., Sedighi, M., Jivkov, A. P. \& Seetharam, S. C. (2021). A model for hydraulic conductivity of compacted bentonite inclusion of microstructure effects under confined wetting. Géotechnique 71, No. 12, 1071-1084, https://doi.org/10.1680/ jgeot.19.P.088.

Idemitsu, K., Tachi, Y., Furuya, H., Inagaki, Y. \& Arima, T. (1995). Diffusion of uranium in compacted bentonites in the reducing condition with corrosion products of iron. MRS Online Proc. Libr. 412, 683-690, https://doi.org/10.1557/PROC-412-683.

IMA-NA (Industrial Minerals Association - North America) (2021). What is bentonite? Washington, DC, USA: Industrial Minerals Association - North America. See https://www. ima-na.org/page/what_is_bentonite (accessed 11/03/2021).

Jacinto, A., Villar, M. \& Ledesma, A. (2012). Influence of water density on the water-retention curve of expansive clays. Géotechnique 62, No. 8, 657-667, https://doi.org/10.1680/geot. 7.00127.

Jové Colón, C. F., Greathouse, J. A., Teich-McGoldrick, S., Cygan, R. T., Weck, P. F., Hansen, G. A., Criscenti, L. J., Caporuscio, F. A., Cheshire, M., Rearick, M. S., McCarney, M. K., Greenberg, H. R., Wolery, T. J., Sutton, M., Zavarin, M., Kersting, A. B., Begg, J. B., Blink, J. A., Buscheck, T., Benedicto-Cordoba, A., Zhao, P., Rutqvist, J., Steefel, C. I., Birkholzer, J., Liu, H. H., Davis, J. A., Tinnacher, R., Bourg, I., Zheng, L. \& Vilarrasa, V. (2013). EBS 
model development and evaluation report, FCRD-UFD2013-000312, SAND2013-8512 P. Albuquerque, NM, USA: Sandia National Laboratories. See https://www.energy.gov/sites/ default/files/2013/12/f5/EBSModelDevelEvaluation.pdf (accessed 18/02/2022)

Liu, J., Yamada, H., Kozaki, T., Sato, S. \& Ohashi, H. (2003). Effect of silica sand on activation energy for diffusion of sodium ions in montmorillonite and silica sand mixture. J. Contam. Hydrol. 61, No. 1-4, 85-93, https://doi.org/10.1016/S0169-7722(02)00115-8.

Mitchell, J. K. \& Soga, K. (2005). Fundamentals of soil behavior, 3rd edn. Hoboken, NJ, USA: John Wiley \& Sons, Inc.

Moore, D. M. \& Reynolds, R. C. (1997). X-ray diffraction and the identification and analysis of clay minerals, 2nd edn. New York, NY, USA: Oxford University Press.

Poppe, L. J., Paskevich, V. F., Hathaway, J. C. \& Blackwood, D. S. (2001). A laboratory manual for X-ray powder diffraction, Open-File Report 2001-41, https://doi.org/10.3133/ofr0141. Reston, VA, USA: United States Geological Survey.

Pusch, R. (2015). Bentonite clay: environmental properties and applications. New York, NY, USA: CRC Press.

Pusch, R. \& Yong, R. N. (2006). Microstructure of smectite clays and engineering performance. New York, NY, USA: Taylor and Francis.
Ransom, B. \& Helgeson, H. C. (1994). A chemical and thermodynamic model of aluminous dioctahedral 2:1 layer clay minerals in diagenetic processes; regular solution representation of interlayer dehydration in smectite. Am. J. Sci. 294, No. 4, $449-484$.

Rautureau, M., Gomes, C. S. F., Liewig, N. \& Katouzian-Safadi, M. (2007). Clays and health: properties and therapeutic uses. Cham, Switzerland: Springer Nature.

Sedighi, M. \& Thomas, H. R. (2014). Micro porosity evolution in compacted swelling clays - a chemical approach. Appl. Clay Sci. 101, 608-618.

Tournassat, C., Bizi, M., Braibant, G. \& Crouzet, C. (2011). Influence of montmorillonite tactoid size on Na-Ca cation exchange reactions. J. Colloid Interf. Sci. 364, No. 2, 443-454.

Vieillard, P., Blanc, P., Fialips, C. I., Gailhanou, H. \& Gaboreau, S. (2011). Hydration thermodynamics of the SWy-1 montmorillonite saturated with alkali and alkaline-earth cations: a predictive model. Geochim. Cosmochim. Acta 75, No. 19, $5664-5685$.

Wikipedia (2021). Bentonite. San Francisco, CA, USA: Wikimedia Foundation, Inc. See https://en.wikipedia.org/wiki/Bentonite (accessed 11/03/2021). 